REPORTS OF MORPHOLOGY
Official Journal of the Scientific Society of Anatomists,
Histologists, Embryologists and Topographic Anatomists
of Ukraine
journal homepage: https://morphology-journal.com

\title{
Quantitative changes in the microstructure of the pancreas under the influence of sublethal dehydration, subsequent readaptation and correction
}

\section{Kovchun V.Yu.}

Medical Institute of Sumy State University, Sumy, Ukraine

\author{
ARTICLE INFO \\ Received: 3 March 2021 \\ Accepted: 21 April 2021 \\ UDC: $616.37: 616.395-092.9$ \\ CORRESPONDING AUTHOR \\ e-mail: vu.kovchun@ukr.net \\ Kovchun V.Yu.
}

\begin{abstract}
Dehydration is a pathological condition caused by insufficient water intake and is accompanied by metabolic disorders that have significant consequences for human health and performance. The endocrine system takes part in a number of functions of the water exchange system, optimizing body fluid volume. In the literature, there is no systematic data on changes in the pancreas under conditions of various types of dehydration. This article is devoted to the study of structural changes in the pancreas in conditions of sublethal degrees of various types of dehydration, followed by readaptation and correction with a drug that has anti-ischemic, membrane-stabilizing, antioxidant, hepatoprotective and immunomodulatory properties that allow to normalize protein, carbohydrate and lipid metabolism. The purpose of the study was to research the features of changes in the endocrine and exocrine parenchyma of the pancreas by the method of morphometry of histological preparations under conditions of sublethal dehydration with subsequent readaptation and correction with thiazotic acid morpholinium salt. The study group consisted of 60 mature male rats, which were simulated sublethal degree of general, cellular and extracellular dehydration by the method of A.D.Soboleva, V.Z.Sikora, J.Ya.Bodnar. After reaching a severe degree of dehydration, part of the rats were transferred to a regular drinking diet, the second part received a corrector drug for 14 days. The animals were withdrawn from the experiment by decapitation under anesthesia on 24th, 44th and 104th days in accordance with the type of dehydration. After analyzing the results obtained, it was found that there were no significant differences in most morphometric parameters under conditions of exposure to sublethal dehydration in comparison with subsequent readaptation. Significant changes in the area of the islets of Langerhans and the area of nuclei of exocrinocytes were revealed under conditions of exposure to various types of sublethal dehydration in comparison with readaptation and correction; in all experimental groups. Other morphometric parameters of the pancreatic parenchyma had changes of varying statistical significance, which depended on the type of dehydration. It has been established that the use of the thiazotic acid morpholinium salt leads to partial restoration of the structural components of the pancreatic parenchyma in comparison with the period of readaptation.
\end{abstract}

Keywords: pancreas, islets of Langerhans, acini, sublethal dehydration, thiazotic acid morpholinium salt.

\section{Introduction}

Water is necessary for the development of life and survival $[1,8,10,13,24]$, this is its participation in metabolism, facilitation of cellular metabolism [3, 22], modulation of normal osmotic pressure, maintenance of electrolyte balance, regulation of body temperature and many others physiological processes [9, 19, 23]. It has been proven that both excessive and insufficient water consumption has a negative effect on the health of our body [2, 11, 14, 26, 28]. Dehydration reduces a person's ability to engage in physical activity and increases the risk of diseases of the cardiovascular, genitourinary and digestive systems. The endocrine system is involved in a number of water metabolism processes, optimizing the flow and excretion of fluid in the body. The pancreas, as an 
organ of the digestive and endocrine systems, undergoes pronounced structural changes under conditions of dehydration [4, 5, 7], as well as during the use of alcohol, opioids and smoking [15, 18, 20, 21, 27]. Therefore, an important issue today is the understanding of risk factors, physiological and pathogenetic links of pancreas diseases, systematization and expansion of data in the world literature on this issue $[6,16,20,25]$.

The aim of the study was to study in the experiment the morphometric features of structural transformations of changes in the parenchyma of the pancreas under the influence of sublethal degree of general, cellular and extracellular dehydration of the organism with the subsequent period of readaptation and correction.

\section{Materials and methods}

To achieve the goal of the experiment, 70 laboratory male adult rats weighing from 160 to $200 \mathrm{~g}$ were used, which were in the vivarium of the Medical Institute of Sumy State University. The experiment was conducted in compliance with the main provisions of the Council of Europe Convention on the Protection of Vertebrate Animals Used for Experimental and Other Scientific Purposes (March 18, 1986), EEC Directive 9609 (November 24, 1986), Resolution of the First National Congress on Bioethics "General ethical principles of animal experiments" (2001), and orders of the Ministry of Health of Ukraine №690 from 23.09.2009, №944 from 14.12.2009, №616 from 03.08.2012 and the laws of Ukraine.

60 rats were divided into 3 experimental groups, each of which included 20 rats with a simulated sublethal degree of different types of dehydration according to the methods of A.D.Soboleva, V.Z.Sikora, J.Ya.Bodnar, proposed in 1975. Subsequently, the animals of each group were divided into subgroups of 10 rats, which were transferred to the usual drinking diet for 14 days, and those that in addition to the usual drinking diet for the same period received thiazotic acid morpholinium salt in a dose of $0.1 \mathrm{ml}$ as a preparation corrector of morphological changes that occurred during the experiment. The calculation of the dose of the preparation for animals was performed taking into account the recommendations of Y.R. Rybolovlev and R.S. Rybolovlev [17]. The control group included 10 rats.

Pancreas material collection, fixation, and sample fabrication were performed according to traditional methods [11]. To determine the structural components of the gland, paraffin sections 5-7 ?m thick were stained with hematoxylin-eosin and Van Gieson. Micropreparations were investigated using a digital image output system "SEO Scan Lab 2.0" (Ukraine).

Morphometric analysis included Langerhans islet area (AIL), pancreatic acinus area (PA), pancreatocyte area (PAC), pancreatocyte nuclei area (PCN), pancreatocyte cytoplasm area (PCAC), and nuclear-cytoplasmic ratio (NCR) determination.

The results of morphometric measurements were processed using the statistical program IBM SPSS Statistic 21. In order to verify the normality of the distribution used Kolmogorov-Smirnov test, the average values are presented as $M \pm m$. The Mann-Whitney test was used to compare the performance in the experimental groups. Statistically significant indicators were considered under the condition $\mathrm{p}<0.05$.

\section{Results}

In rats of the control group, the average size of AlL (area of islets of Langerhans) was $13934.1 \pm 636.92 \mu \mathrm{m}^{2}$, PA (pancreatic acinus area) - 983.4 $\pm 67.1{\mu m^{2}}^{2}$ PAC (pancreatocyte area) - 149.5 $\pm 3.16 \mu \mathrm{m}^{2}$; PCN (pancreatocyte nuclei area) - 10.70 $\pm 0.41 \mu \mathrm{m}^{2}$; PCAC (pancreatocyte cytoplasm area) - 138.7 $\pm 4.72 \mu \mathrm{m}^{2}$; NCR (nuclearcytoplasmic ratio) $-8.200 \pm 0.980$ (Fig. 1).

Under the influence of sublethal degree of different types of dehydration, pronounced structural changes were observed in all experimental groups (Fig. 2).

Under the influence of sublethal degree of general dehydration and the period of further readaptation, there was a decrease in the area of AlL - by $3.5 \%(p=0.880), P A-$ by $1.4 \%(p=1.0)$, PAC - by $1.96 \%(p=0.571), P C A C-$ by $1.42 \%$ $(p=0.650), P C N-$ by $6.7 \%(p=0.151), N C R$ - by $5,93 \%$ $(p=0.364)$. Under the conditions of using the thiazotic acid morpholinium salt, we observed a decrease in AIL - by $32.27 \%(p<0.001), P A-$ by $15,91 \%(p=0.041), P A C-$ by $7.42 \%$ $(p=0.096), P C A C$ - by $6,21 \%(p=0.290), P C N-$ by $17.82 \%$ $(p=0.038), N C R-$ by $12.71 \%(p=0.406)$. Comparing the periods of readaptation and correction, a decrease in Langerhans islet area by $29.8 \%(p<0.001)$, acinus area by $14,67 \% \quad(p=0.019)$, pancreatocyte area - by $5.57 \%$ $(p=0.051)$, pancreatocyte cytoplasm area - by $4.85 \%$ $(p=0.406)$, pancreatocyte nuclei area - by $11.97 \%(p=0.290)$, nuclear-cytoplasmic ratio - by $7.2 \%(p=0.597)$. Detailed morphometric changes in the parenchyma of the pancreas conditions of the sublethal degree of general dehydration, the period of subsequent readaptation and correction are shown in Table 1.

Under the influence of sublethal degree of cellular

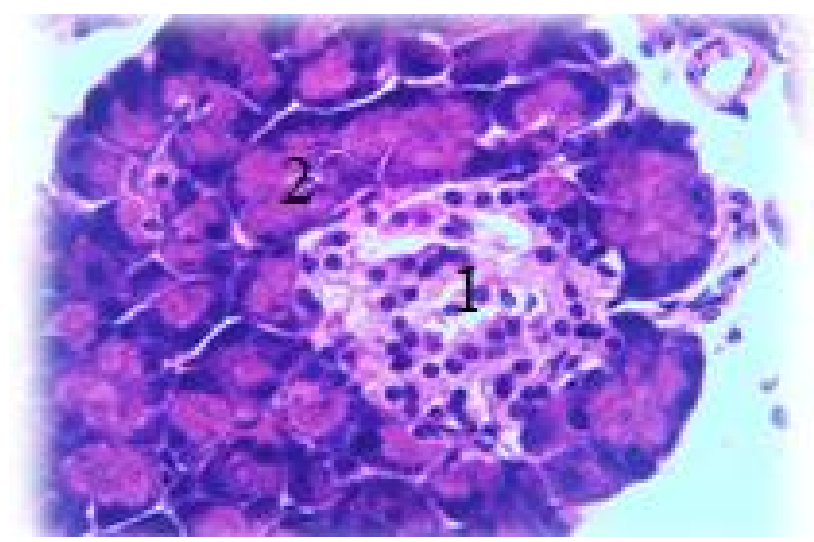

Fig. 1. Pancreas of the rat from control group: 1 - islet of Langerhans, 2 - acini. Hematoxylin-eosin. x400. 

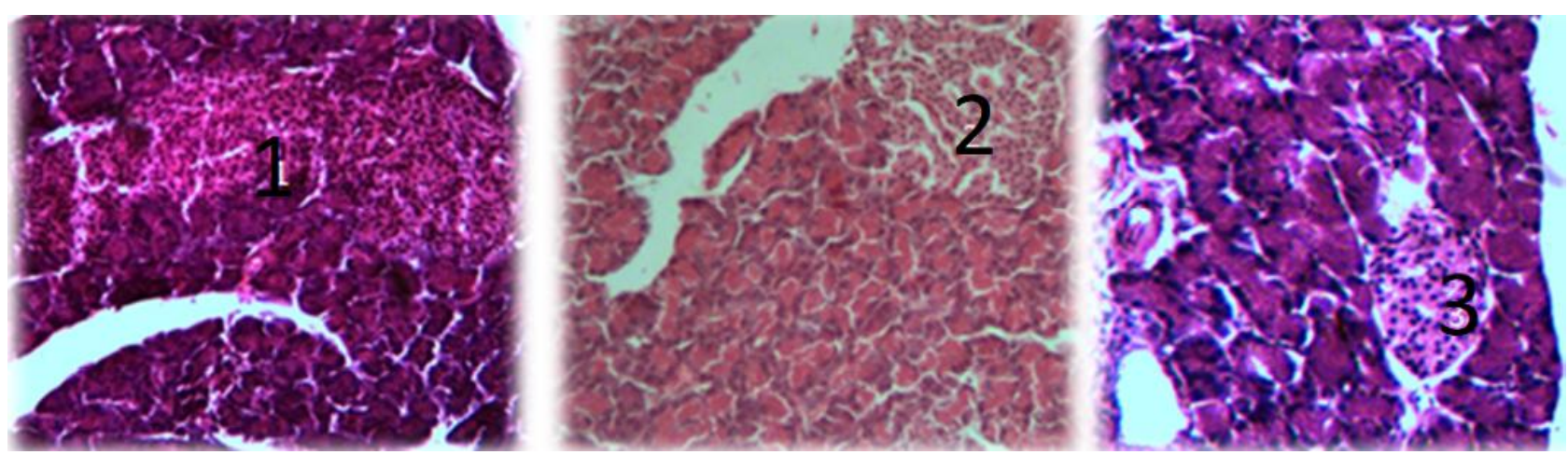

Fig. 2. The islet of Langerhans of the rat pancreas: 1 - under conditions of general dehydration, 2 - cellular dehydration, 3 - extracellular dehydration. Hematoxylin-eosin. x200.

Table 1. Morphometric changes of islets, acini and pancreatocytes under conditions of sublethal degree of general dehydration, period of readaptation and correction.

\begin{tabular}{|c|c|c|c|c|}
\hline Indicator & Control & Severe dehydration & Readaptation & Correction \\
\hline \multirow{2}{*}{ AlL, $\mu \mathrm{m}^{2}$} & $13934.1 \pm 636.92$ & $31280.9 \pm 1992.7$ & $30176.7 \pm 1144.1$ & $21184.01 \pm 1992.1$ \\
\hline & \multicolumn{4}{|c|}{$p_{1}=0.880 ; p_{2}<0.001 ; p_{3}<0.001$} \\
\hline \multirow{2}{*}{$\mathrm{PA}, \mu \mathrm{m}^{2}$} & $983.4 \pm 67.1$ & $1326.2 \pm 69.7$ & $1307.4 \pm 64.1$ & $1115.5 \pm 34.9$ \\
\hline & \multicolumn{4}{|c|}{$p_{1}=1.0 ; p_{2}=0.041 ; p_{3}=0.019$} \\
\hline \multirow{2}{*}{ PAC, $\mu \mathrm{m}^{2}$} & $149.5 \pm 3.16$ & $172.4 \pm 5.8$ & $169.0 \pm 5.0$ & $159.6 \pm 5.1$ \\
\hline & \multicolumn{4}{|c|}{$p_{1}=0.571 ; p_{2}=0.096 ; p_{3}=0.151$} \\
\hline \multirow{2}{*}{ PCAC, $\mu \mathrm{m}^{2}$} & $138.7 \pm 4.7$ & $154.5 \pm 5.9$ & $152.3 \pm 5.2$ & $144.9 \pm 5.4$ \\
\hline & \multicolumn{4}{|c|}{$p_{1}=0.650 ; p_{2}=0.290 ; p_{3}=0.406$} \\
\hline \multirow{2}{*}{$\mathrm{PCN}, \mu \mathrm{m}^{2}$} & $10.76 \pm 0.41$ & $17.91 \pm 0.52$ & $16.69 \pm 1.14$ & $14.65 \pm 0.94$ \\
\hline & \multicolumn{4}{|c|}{$p_{1}=0.151 ; p_{2}=0.038 ; p_{3}=0.290$} \\
\hline NCR, \% & $8.270 \pm 0.984$ & $11.80 \pm 0.83$ & $11.11 \pm 0.92$ & $10.31 \pm 0.93$ \\
\hline
\end{tabular}

Notes: $p_{1}$ - the probability of differences in the indicators of severe general dehydration and the period of readaptation; $p_{2}-$ probability of differences in indicators of severe general dehydration and correction period; $p_{3}$ - the probability of differences in readaptation and correction. AIL - Langerhans islet area; PA - pancreatic acinus area; PAC - pancreatocyte area; PCAC - pancreatocyte cytoplasm area; PCN - pancreatocyte nuclei area; NCR - nuclear-cytoplasmic ratio.

dehydration and the period of readaptation, there was a decrease in AlL - by $2.86 \%(p=0.762)$, pancreatocyte nuclei area - by $10.55 \%(p=0.199)$, nuclear-cytoplasmic ratio - by $16.22 \%(p=0.112)$, and increase of acinus area by $2.49 \%$ $(p=0.705)$, pancreatocyte area - by $2.82 \%(p=0.364)$, pancreatocyte cytoplasm area - by $6.47 \%(p=0.041)$. Under the conditions of simultaneous use of the thiazotic acid morpholinium salt, we observed a decrease in AIL - by $24.85 \%(p<0.001), P C N-$ by $25.62 \%(p=0.019), N C R-$ by $42.26 \%(p<0.001)$, and increase of $P A-$ by $6.69 \%(p=0.762)$, PAC - by $17.45 \%$, PCAC - by $28.79 \%$ ( $p<0.001)$. Comparing the periods of readaptation and correction revealed a decrease in AIL (Langerhans islet area) - by $22,63 \%$ $(p=0,01), P C N$ (pancreatocyte nuclei area) - by $16.85 \%$ $(p=0.130)$, NCR (nuclear-cytoplasmic ratio) - by $31.08 \%$ $(p=0.04)$, and increase of PA (acinus area ) - by $4.35 \%$ $(p=0.406), P A C$ (pancreatocyte area ) - by $14.22 \%(p=0.004)$, PCAC (pancreatocyte cytoplasm area) - by $20.96 \%$ $(p<0.001)$. Detailed morphometric changes in the parenchyma of the pancreas conditions of sublethal degree of cellular dehydration, the period of subsequent readaptation and correction are shown in Table 2 .

Under the influence of sublethal degree of extracellular dehydration and the period of subsequent readaptation, there was an increase in AIL - by $7.04 \%(p=0.131)$, PA - by $3.16 \%(p=0.406)$, PAC - by $10.9 \%(p=0.07), P C A C-$ by $19.57 \%(p=0.023)$, and reducing of $P C N-$ by $16.42 \%$ $(p=0.005), N C R-$ by $31.61 \%(p=0.003)$. Under the conditions of simultaneous use of the thiazotic acid morpholinium salt, we observed an increase in AIL - by $17.04 \%(p=0.013), P A-$ by $9.84 \%(p=0.082), P A C$ - by $18.93 \%$ $(p=0.007), P C A C$ - by $34.71 \%(p<0,001)$, and reducing of PCN - by $30.43 \%(p<0.001)$, NCR - by $49.24 \%(p<0.001)$. Comparing the periods of readaptation and correction revealed an increase in AIL - by $9.33 \%(p=0.059), P A$ - by $6.48 \%(p=0.226)$, PAC - by $7.23 \%(p=0.096)$, PCAC - by $12.65 \%(p=0.038), P C N$ - by $16.76 \%(p=0.010)$ and only nuclear-cytoplasmic ratio and reduced by $25.77 \%$ 
Table 2. Morphometric changes of islets, acini and pancreatocytes under conditions of sublethal degree of cellular dehydration, period of readaptation and correction.

\begin{tabular}{|c|c|c|c|c|}
\hline Indicator & Control & Severe dehydration & Readaptation & Correction \\
\hline \multirow{2}{*}{ AlL, $\mu \mathrm{m}^{2}$} & $13934.1 \pm 636.9$ & $25774.2 \pm 1316.3$ & $25035.6 \pm 979.6$ & $19368.6 \pm 701.3$ \\
\hline & \multicolumn{4}{|c|}{$\mathrm{p}_{1}=0.762 ; \mathrm{p}_{2}<0.001 ; \mathrm{p}_{3}<0.001$} \\
\hline \multirow{2}{*}{$\mathrm{PA}, \mu \mathrm{m}^{2}$} & $983.4 \pm 67.1$ & $800.8 \pm 57,2$ & $820.8 \pm 33.1$ & $856.6 \pm 29.1$ \\
\hline & \multicolumn{4}{|c|}{$p_{1}=0.705 ; p_{2}=0.762 ; p_{3}=0.406$} \\
\hline \multirow{2}{*}{ PAC, $\mu m^{2}$} & $149.5 \pm 3.1$ & $95.72 \pm 1.25$ & $98.42 \pm 1.79$ & $112.4 \pm 2.8$ \\
\hline & \multicolumn{4}{|c|}{$p_{1}=0.364 ; p_{2}<0.001 ; p_{3}=0.004$} \\
\hline \multirow{2}{*}{ PCAC, $\mu m^{2}$} & $138.7 \pm 4.7$ & $75.75 \pm 1.29$ & $80.61 \pm 1.59$ & $97.52 \pm 2.53$ \\
\hline & \multicolumn{4}{|c|}{$p_{1}=0.041 ; p_{2}<0.001 ; p_{3}<0.001$} \\
\hline \multirow{2}{*}{$\mathrm{PCN}, \mu \mathrm{m}^{2}$} & $10.76 \pm 0.41$ & $19.94 \pm 1.23$ & $17.81 \pm 1.31$ & $14.81 \pm 1.18$ \\
\hline & \multicolumn{4}{|c|}{$p_{1}=0.199 ; p_{2}=0.019 ; p_{3}=0.130$} \\
\hline \multirow{2}{*}{ NCR, \% } & $8.241 \pm 0.99$ & $26.54 \pm 1.93$ & $22.22 \pm 1.79$ & $15.29 \pm 1.22$ \\
\hline & \multicolumn{4}{|c|}{$p_{1}=0.112 ; p_{2}<0.001 ; p_{3}=0.04$} \\
\hline
\end{tabular}

Notes: $p_{1}$ - the probability of differences in the indicators of severe cellular dehydration and the period of readaptation; $p_{2}$ - the probability of differences in the indicators of severe cellular dehydration and the correction period; $p_{3}$ - the probability of differences in readaptation and correction. AIL - Langerhans islet area; PA - pancreatic acinus area; PAC - pancreatocyte area; PCAC - pancreatocyte cytoplasm area; PCN - pancreatocyte nuclei area; NCR - nuclear-cytoplasmic ratio.

Table 3. Morphometric changes of islets, acini and pancreatocytes under conditions of sublethal degree of extracellular dehydration, period of readaptation and correction.

\begin{tabular}{|c|c|c|c|c|}
\hline Indicator & Control & Severe dehydration & Readaptation & Correction \\
\hline \multirow{2}{*}{ AlL, $\mu \mathrm{m}^{2}$} & $13934.1 \pm 636.92$ & $10925.41 \pm 655.25$ & $11695.4 \pm 385.01$ & $12787.4 \pm 246.1$ \\
\hline & \multicolumn{4}{|c|}{$p_{1}=0.131 ; p_{2}=0.013 ; p_{3}=0.059$} \\
\hline \multirow{2}{*}{$\mathrm{PA}, \mu \mathrm{m}^{2}$} & $983.4 \pm 67.1$ & $784.3 \pm 29.2$ & $809.1 \pm 31.1$ & $861.5 \pm 27.00$ \\
\hline & \multicolumn{4}{|c|}{$p_{1}=0.406 ; p_{2}=0.082 ; p_{3}=0.226$} \\
\hline \multirow{2}{*}{ PAC, $\mu \mathrm{m}^{2}$} & $149.5 \pm 3.16$ & $86.14 \pm 3.59$ & $95.49 \pm 2.51$ & $102.4 \pm 2.9$ \\
\hline & \multicolumn{4}{|c|}{$p_{1}=0.070 ; p_{2}=0.007 ; p_{3}=0.096$} \\
\hline \multirow{2}{*}{ PCAC, $\mu \mathrm{m}^{2}$} & $138.7 \pm 4.72$ & $65.41 \pm 3.76$ & $78.21 \pm 2.82$ & $88.12 \pm 3.31$ \\
\hline & \multicolumn{4}{|c|}{$p_{1}=0.023 ; p_{2}<0.001 ; p_{3}=0.038$} \\
\hline \multirow{2}{*}{$\mathrm{PCN}, \mu \mathrm{m}^{2}$} & $10.74 \pm 0.41$ & $20.74 \pm 0.85$ & $17.30 \pm 0.62$ & $14.40 \pm 0.65$ \\
\hline & \multicolumn{4}{|c|}{$p_{1}=0.005 ; p_{2}<0.001 ; p_{3}=0.010$} \\
\hline \multirow{2}{*}{$\mathrm{NCR}, \%$} & $8.27 \pm 0.98$ & $32.87 \pm 2.61$ & $22.51 \pm 1.34$ & $16.69 \pm 1.22$ \\
\hline & \multicolumn{4}{|c|}{$p_{1}=0.003 ; p_{2}<0.001 ; p_{3}=0.005$} \\
\hline
\end{tabular}

Notes: $p_{1}$ - the probability of differences in the indicators of severe extracellular dehydration and the period of readaptation; $p_{2}-$ the probability of differences in the indicators of severe extracellular dehydration and the correction period; $p_{3}$ - the probability of differences in readaptation and correction. AIL - Langerhans islet area; PA - pancreatic acinus area; PAC - pancreatocyte area; PCAC - pancreatocyte cytoplasm area; PCN - pancreatocyte nuclei area; NCR - nuclear-cytoplasmic ratio.

$(p=0.005)$. Detailed morphometric changes in the parenchyma of the pancreas conditions of sublethal degree of extracellular dehydration, the period of subsequent readaptation and correction are shown in Table 3.

\section{Discussion}

Water is one of the main components of the human body, which is vital for the performance of physiological processes, thermoregulation, and transport of nutrients $[1,6,7,8]$. Water consumption is influenced by numerous factors, including temperature, humidity, as well as the level of physical activity and lifestyle [15, 18, 21, 27]. The most vulnerable groups to dehydration are children and adolescents, who are prone to excessive water loss, especially during physical activity and may not be aware of the need to restore lost fluid [26, 28].

Numerous literature data confirm that disability and mortality from cardiovascular diseases and diseases of the gastrointestinal tract are inversely proportional to water intake $[10,14,19,25]$.

Analyzing the results, it was found that the histostructure of the pancreas, endocrine system and gastrointestinal 
tract, undergoes pronounced structural changes under the influence of sublethal degree of various types of dehydration, which coincides with the data of L.M.Davydova with co-authors (2017), who noted similar morphological changes in the structural components of the tongue in violation of water-electrolyte balance [4]. The absence of significant differences in indicators in the experimental groups under the influence of sublethal dehydration and the period of readaptation was established.

However, under conditions of sublethal degree of general dehydration and the subsequent period of correction with the thiazotic acid morpholinium salt, statistically significant changes were detected in the form of a decrease in the areas of the islets of Langerhans, acini and exocrinocyte nuclei. Comparative analysis of the size of the results of the periods of readaptation and correction showed significant changes in the area of the islets of Langerhans and the area of the acini.

Analysis of the sublethal degree of cellular dehydration and the subsequent period of correction with the thiazotic acid morpholinium salt revealed a significant increase in the areas of exocrinocytes and cytoplasm of exocrinocytes, with a simultaneous decrease in the areas of islets of Langerhans, nuclei of exocrinocytes and nuclear cytoplasms. The obtained results of the periods of readaptation and correction show statistically significant changes in the indicators of the areas of the islets of

\section{References}

[1] Ali, H., Al Dhaheri, A., Elmi, F., Ng, S., Zaghloul, S., Ohuma, E., \& Qazaq, H. (2019). Water and Beverage Consumption among a Nationally Representative Sample of Children and Adolescents in the United Arab Emirates. Nutrients, 11(9), 2110. doi: $10.3390 /$ nu11092110

[2] Barley, O., Chapman, D., \& Abbiss, C. (2020). Reviewing the current methods of assessing hydration in athletes. Journal of the International Society of Sports Nutrition, 17(1). doi: 10.1186/s12970-020-00381-6

[3] Bruni, A., Bornstein, S., Linkermann, A., \& Shapiro, A. (2018). Regulated Cell Death Seen through the Lens of Islet Transplantation. Cell Transplantation, 27(6), 890-901. doi: 10.1177/0963689718766323

[4] Davydova, L., Tkach, G., German, S., Bushtruk, A., \& Maksymova, O. (2017). Особливості морфогенезу язика щурів при порушенні водно-електролітного балансу організму [Features of morphogenesis of rat tongue in violation of water-electrolyte balance of the organism]. Здобутки клінічної і експериментальної медицини - Achievements of Clinical and Experimental Medicine, 1(3). doi: 10.11603/ 1811-2471.2017.v1.i3.7956

[5] Davydova, L., Tkach, G., Tymoshenko, A., Moskalenko, A., Sikora, V., Kyptenko, L., Lyndin, M. ... Suchonos, O. (2017). Anatomical and morphological aspects of papillae, epithelium, muscles, and glands of rats' tongue: Light, scanning, and transmission electron microscopic study. Interventional Medicine and Applied Science, 9(3), 168-177. doi: 10.1556/1646.9.2017.21

[6] Cheuvront, S., Kenefick, R., Charkoudian, N., \& Sawka, M. (2013). Physiologic basis for understanding quantitative dehydration assessment. The American Journal of Clinical Nutrition, 97(3), 455-462. doi: 10.3945/ajcn.112.044172
Langerhans, exocrinocytes, cytoplasm of exocrinocytes and nuclear-cytoplasmic ratio.

However, under conditions of sublethal degree of extracellular dehydration and the subsequent period of correction, significant changes in the areas of islets of Langerhans, exocrinocytes and cytoplasm of exocrinocytes in the form of their increase, with a probable decrease in the area of exocrinocyte nuclei and nuclear cytoplasmic ratio. Comparison of readaptation and correction indicators shows statistically significant changes in the indicators of cytoplasm areas of exocrinocytes, exocrinocyte nuclei and nuclear-cytoplasmic ratio.

Prospects for further research are to study the ultramorphometric characteristics of the parenchyma of the pancreas under different types of dehydration.

\section{Conclusions}

1. The use of thiazotic acid morpholinium salt as a corrective drug for changes that have occurred under conditions of various types of dehydration of the body, leads to a reliable leveling of changes in the structural components of the pancreatic parenchyma, compared with readaptation.

2. The most reversible changes that are easier to correct are observed in conditions of general dehydration, while the deepest changes that are most difficult to correct are found in conditions of extracellular dehydration.

[7] Gamble, J., \& Mclver, M. (1928). Body fluid changes due to continued loss of the external secretion of the pancreas. Journal of Experimental Medicine, 48(6), 859-869. doi: 10.1084/jem.48.6.859

[8] James, L., Funnell, M., James, R., \& Mears, S. (2019). Does Hypohydration Really Impair Endurance Performance? Methodological Considerations for Interpreting Hydration Research. Sports Medicine, 49(S2), 103-114. doi: 10.1007/ s40279-019-01188-5

[9] Johnson, R., Lichtenstein, A., Anderson, C., Carson, J., Despres, J., Hu, F. ... Wylie-Rosett, J. (2018). Low-Calorie Sweetened Beverages and Cardiometabolic Health: A Science Advisory From the American Heart Association. Circulation, 138(9). doi: 10.1161/cir.0000000000000569

[10] Malisova, O., Athanasatou, A., Pepa, A., Husemann, M., Domnik, K., Braun, H. ... Kapsokefalou, M. (2016). Water Intake and Hydration Indices in Healthy European Adults: The European Hydration Research Study (EHRS). Nutrients, 8(4), 204. doi: 10.3390/nu8040204

[11] Merkulov, G.A. (1969). Курс патологической техники [Pathological Technique Course]. М.: Медицина - М.: Medicine.

[12] Monaghan, T., Kavoussi, A., Agudelo, C., Rahman, S., Michelson, K., \& Bliwise, D. et al. (2020). Nocturnal Urine Production in Women With Global Polyuria. International Neurourology Journal, 24(3), 270-277. doi: 10.5213/inj.2040166.083.

[13] Munoz, C., Johnson, E., McKenzie, A., Guelinckx, I., Graverholt, G., \& Casa, D. et al. (2015). Habitual total water intake and dimensions of mood in healthy young women. Appetite, 92, 81-86. doi: 10.1016/j.appet.2015.05.002

[14] Özen, A., Bibiloni, M., Bouzas, C., Pons, A., \& Tur, J. (2018). 
Beverage Consumption among Adults in the Balearic Islands: Association with Total Water and Energy Intake. Nutrients, 10(9), 1149. doi: 10.3390/nu10091149

[15] Lugea, A., Gerloff, A., Su, H., Xu, Z., Go, A., \& Hu, C. et al. (2017). The Combination of Alcohol and Cigarette Smoke Induces Endoplasmic Reticulum Stress and Cell Death in Pancreatic Acinar Cells. Gastroenterology, 153(6), 1674-1686. doi: 10.1053/j.gastro.2017.08.036

[16] Reid, I. (1994). Role of Nitric Oxide in the Regulation of Renin and Vasopressin Secretion. Frontiers in Neuroendocrinology, 15(4), 351-383. doi: 10.1006/frne.1994.1014

[17] Rybolovlev, Yu.R., \& Rybolovlev, R.S. (1979). Дозирование веществ для млекопитающих по константе биологической активности [Dosing of substances for mammals according to the constant of biological activity]. Доклады $A H$ CCCP - Reports of the USSR Academy of Sciences.

[18] Sahin-Toth, M., \& Hegyi, P. (2017). Smoking and Drinking Synergize in Pancreatitis: Multiple Hits on Multiple Targets. Gastroenterology, 153(6), 1479-1481. doi: 10.1053/ j.gastro.2017.10.031

[19] Savoie, F., Kenefick, R., Ely, B., Cheuvront, S., \& Goulet, E. (2015). Effect of Hypohydration on Muscle Endurance, Strength, Anaerobic Power and Capacity and Vertical Jumping Ability: A Meta-Analysis. Sports Medicine, 45(8), 1207-1227. doi: 10.1007/s40279-015-0349-0

[20] Sharon, N., Chawla, R., Mueller, J., Vanderhooft, J., Whitehorn, L., Rosenthal, B. ... Melton, D. (2019). A Peninsular Structure Coordinates Asynchronous Differentiation with Morphogenesis to Generate Pancreatic Islets. Cell, 176(4), 790-804.e13. doi: 10.1016/j.cell.2018.12.003

[21] Srinivasan, M.P., Bhopale, K.K., Caracheo, A.A., Amer, S.M., Khan, S., Kaphalia, L. ... Kaphalia, B.S. (2020). Activation of AMP-activated protein kinase attenuates ethanol-induced ER/ oxidative stress and lipid phenotype in human pancreatic acinar cells. Biochemical Pharmacology, 180, 114174. doi: 10.1016/j.bcp.2020.114174

[22] Scratcherd, T., Hutson, D., \& Case, R.M. (1981). lonic transport mechanisms underlying fluid secretion by the pancreas. Philosophical Transactions of the Royal Society B., 296(1080), 167-178. doi: 10.1098/rstb.1981.0180

[23] Tan, B., Philipp, M., Hill, S., Che Muhamed, A., \& Mündel, T. (2020). Pain Across the Menstrual Cycle: Considerations of Hydration. Frontiers in Physiology, 11. doi: 10.3389/ fphys.2020.585667

[24] Vieux, F., Maillot, M., Constant, F., \& Drewnowski, A. (2017). Water and beverage consumption patterns among 4 to 13year-old children in the United Kingdom. BMC Public Health, 17(1). doi: 10.1186/s12889-017-4400-y

[25] Villiger, M., Stoop, R., Vetsch, T., Hohenauer, E., Pini, M., Clarys, P. ... Clijsen, R. (2017). Evaluation and review of body fluids saliva, sweat and tear compared to biochemical hydration assessment markers within blood and urine. European Journal of Clinical Nutrition, 72(1), 69-76. doi: 10.1038/ejcn.2017.136

[26] Zhang, J., Zhang, N., Liu, S., Du, S., He, H., \& Ma, G. (2021). The comparison of water intake patterns and hydration biomarkers among young adults with different hydration statuses in Hebei, China. Nutrition \& Metabolism, 18. doi: 10.1186/s12986-020-00531-2

[27] Zhang, J., Zhang, N., Wang, Y., Liang, S., Liu, S., Du, S. ... Ma, G. (2020). Drinking patterns and hydration biomarkers among young adults with different levels of habitual total drinking fluids intake in Baoding, Hebei Province, China: a crosssectional study. BMC Public Health, 20(1). doi: 10.1186/ s12889-020-08558-z

[28] Zhang, J., Zhang, N., He, H.R., Cai, H., Yan, X.Y., Guo, X.H. ... Ma, G. (2019). The total fluids intake, volume of urine and hydration status among young adults from Hebei Province in spring. Zhonghua Yu Fang Yi Xue Za Zhi, 53(4), 6. doi: 10.3760/cma.j.issn.0253-9624.2019.04.005

\section{КІЛЬКІСНІ ЗМІНИ МІКРОСТРУКТУРИ ПІДШЛУНКОВОЇ ЗАЛОЗИ ЗА УМОВ ВПЛИВУ СУБЛЕТАЛЬНОГО ЗНЕВОДНЕННЯ, ПОДАЛЬШОÏ РЕАДАПТАЦІї ТА КОРЕКЦІї \\ Ковчун В.Ю.}

Зневоднення - це патологічний стан, що викликаний недостатнім надходженням води та супроводжується метаболічними порушеннями, які мають значні наслідки для здоров'я та працездатності людини. Ендокринна система приймає участь у низці фрункиій системи обміну води, оптимізуючи об'єм рідини організму. У літературі немає систематизованих даних щодо змін підшлункової залози за умов різних видів зневоднення. Актуальним є вивчення структурних порушень підилункової залози за умов сублетальних ступенів різних видів зневоднення з подальшою реадаптацією та корекцією препаратом, котрий має протиішемічну, мембраностабілізуючу, антиоксидантну, гепатопротекторну та імуномодулюючу властивості, що дозволяє нормалізувати білковий, вуглеводний та ліпідний обмін. Метою дослідження було вивчення особливостей змін ендокринної та екзокринної паренхіми підшлункової залози методом морфометрії гістологічних препаратів за умов сублетального зневоднення з подальшою реадаптацією та корекцією морфолінієвою сіллю тіазотної кислоти. Досліджувану групу становили 60 зрілих щурів-самців, котрим моделювали сублетальний ступінь загального, клітинного та позаклітинного зневоднення за А.Д.Соболєвою, В.З.Сікорою, Я.Я.Боднаром. Після досягнення тяжкого ступеня зневоднення частину щурів переводили на звичайний питний раціон, друга частина отримувала препарат-коректор впродовж 14 діб. Тварин було виведено з експерименту шляхом декапітації під наркозом на 24, 44 та 104 добу відповідно до виду зневоднення. Проаналізувавши отримані результати, встановлено відсутність статистично значущих відмінностей більщості морфометричних показників за умов впливу сублетального зневоднення порівняно з подальшою реадаптацією всіх експериментальних груп тварин. Виявлено достовірні зміни площі острівців Лангерганса та площі ядер екзокриноцитів за умов впливу різних видів сублетального зневоднення у порівнянні з групою реадаптації та групою корекції в усіх експериментальних групах. Інші морфометричні показники паренхіми підшлункової залози мали зміни різної статистичної значущості, котрі залежали від виду зневоднення. З'ясовано, що застосування морфолінієвої солі тіазотної кислоти призводить до часткового відновлення структурних компонентів паренхіми підшлункової залози, порівняно з періодом реадаптації.

Ключові слова: підшлункова залоза, острівці Лангерганса, ацинуси, сублетальне зневоднення, морфолінієва сіль тіазотної кислоти. 